\title{
Prevalence Proportion of Patient with Coronary Heart Disease in Inpatient Room of RSUD Dr. Soetomo Surabaya in 2017
}

\author{
Faradila Budi Saputri ${ }^{1}$, Dyah Fauziah ${ }^{2}$, Esti Hindariati ${ }^{3 *}$ \\ ${ }^{1}$ Faculty of Medicine, Universitas Airlangga, Surabaya, Indonesia \\ ${ }^{2}$ Department of Pathology Anatomy, Faculty of Medicine, Universitas Airlangga - Dr. Soetomo General Hospital, \\ Surabaya, Indonesia \\ ${ }^{3}$ Department of Cardiology and Vascular Medicine, Faculty of Medicine, Universitas Airlangga - Dr. Soetomo General \\ Hospital , Surabaya, Indonesia
}

\section{A R T I C L E I N F O}

\section{Article history:}

Received 18 September 2020

Received in revised form 26

October 2020

Accepted 29 October 2020

Available online 31 October 2020

Keywords:

Hypertension,

Coronary Heart Disease,

Dyslipidemia,

Diabetes Mellitus.

*) Corresponding author:

ehindariati@yahoo.com

\begin{abstract}
A B S T R A C T
Introduction: Coronary heart disease (CHD) is the most common type of heart disease that causes death. It occurs as a result of hardening of the coronary arteries which supply oxigen-rich blood to the entire heart muscle so that the heart can contract properly. However, many patients neglect the symptoms. Moreover, the risk factor and the comorbides disease worsen the condition. This research aims to study the profile of coronary heart disease patients in the inpatient rooms at Dr. Soetomo General Hospital Surabaya in 2017.

Methods: This study was a cross-sectional and retrospective study by assessing patients' medical record and analyzed descriptively.

Results: From total 587, 263 patiens met inclusion criteria, aged between 51-60 years $(42.6 \%)$ with domination of male $(82,13 \%)$. \%). Risk Factors are into one of the Comorbidities of CHD Patient. There are Risk Factor can be aggravate of CHD Patients. Most of subjects had risk factor hipertension $(50,79 \%)$, and hypertension with DM (38,7\%). Hypertension based on systolic pressure and diastolic pressure obtained that systolic pressure $<120 \mathrm{mmhg}$ was $39.6 \%$ and diastolic pressure $<80$ was $37.4 \%$.

Conclusion: Most of CHD patients in this study were in age group $51-60$ years old, male, had risk factor hypertension and DM.
\end{abstract}

\section{Introduction}

Coronary heart disease (CHD) is caused by the abnormality on the arteries of the coronary experienced thickening on the wall blood vessels and interrupt the flow blood heading to the muscles of the heart impairs its functions blood to the entire body. ${ }^{1}$ Cardiovascular disease is a non-communicable disease contributing to a high mortality rate in the world. Mortality number of cardiovascular disease in the world in 2008 were 17 millions. This numbers are predicted that will increase year by year until it will reach 25 millions of mortality in 2030. The death rate due to cardiovascular in Indonesia is still high. ${ }^{2}$ According to mortality numbers, there were 56.9 millions mortality in the world in 2016, it was more than half of $54 \%$ mortality caused by ischemic heart disease and stroke as the biggest leading mortality in the world which caused 15.2 millions mortality in 2016 and has became the first leading mortality in global for last 15 years. ${ }^{3}$ Risk factors for CHD have been identified by various studies outside, but research on risk factors for CHD has not been identified in Dr.Soetomo General Hospital. Even though these risk factors can be used to prevent prevention, diagnosis, and therapy. In addition, profiles regarding risk factors can also be used as materials for further implementation.

Therefore, this research on coronary heart disease profile is made for clinical purposes for diagnosis and other therapies as well as for material in further research at inpatient room in cardiovascular unit of Dr. Soetomo General Hospital, Surabaya in 2017

\section{Methods}

This research was a cross sectional study to describe the profile of CHD patients in the inpatient room in the 
cardiovascular unit of Dr. Soetomo General Hospital, Surabaya. The study Design and protocol were approved by the Ethics Committee of Dr.Soetomo General Hospital, Surabaya (Sertificate Number 0056/KEPK/II/2018).

The study population was all patients with CHD that hospitalized at Dr. Soetomo General Hospital, Surabaya from January - December 2017. The inclusion criteria was patient with CHD in inpatient room in the cardiovascular unit of Dr. Soetomo General Hospital. In assessment part on medical record at least 1 time, over the period given, by the doctor on duty. The exclusion criteria were incomplete medical record, missings medical record.

This study used secondary data from medical records. All Subjects were collected who had some variable with seen From Demography Patients seen Sex and Age patients. History of comorbid disease such as patients with comorbidities such as hypertension comorbidity, Diabetes mellitus (DM) comorbidity, patients with dyslipidemia that can shown from laboratory result found high LDL and combined from those comorbidities. Another variable in this research are found from hypertension level. This hypertension level seen from blood pressure levels systol and dyastol. The analyzed data were then analyzed using IBM SPSS ver.16 for normality and then processed using Microsoft Excel 2010. Quantitative variables were presented as percentages or number of samples for categorical variables.

\section{Results}

Numbers of patients with coroner heart who were stayed at inpatient rooms in cardiovascular unit of Dr. Soetomo General Hospital, Surabaya in 2017 were 587 patients. 263 patients were included in this research, while 324 patients were exclude, in details: 233 patients admitted not under diagnose of atherosclerosis but others such as: Old myocardial infarction, aneurysm, and other causes. There were 66 patients with CHD who stayed in inpatients room other than cardiovascular unit. There were 25 data of medical record were lost and it had not been found yet.

Of 263 patients, $216(82.1 \%)$ were male and 47 $(17.9 \%)$ were female with most in age range of 51-60 years $(42.6 \%)$. The average of age of patients was 57.11 years $(\mathrm{SD} \pm 9,472)$. the youngest patient in this research was 27 years, where as the oldest patient in this research was 83 years. The results showed that the age of 51-60 years is most at risk of CHD.

Risk factors are into one of the comorbidities of CHD Patient. From the comorbidity data, the domination patients who had hypertension were 97(50.8\%), patients with no comorbidity of DM of 109 patients $(66.6 \%)$ and patients with normal lipid who laboratorium result were normal LDL of 116 (60.42\%). Patients of CHD with more than 1 comorbidities as seen in table were with DM and HT 29 patients $(38.7 \%)$.

From the physical examination from blood pressure result of 263 patients, a number of $72(39,6 \%)$ patients with normal blood pressure had normal systolic blood pressure under $120 \mathrm{mmhg}$ and as most patients had normal systolic pressure, while diastol level shown that most patients with level diastol $82 \mathrm{mmHg}$. Most patients with CHD were men who have had history of disease with HT and DM. However, from the results of the hypertension staging, many patients had normal blood pressure. This can happen because when taking data on the medical record, the patient has taken anti-hypertension drugs so that the coronary heart patient data has normal blood pressure.

Table 1. Profile of patients with CHD

\begin{tabular}{|c|c|c|}
\hline Variable & $\mathrm{n}$ & Percentage $(\%)$ \\
\hline Age & $\mathrm{n}=263$ & \\
\hline$\leq 30$ years & 1 & 0,4 \\
\hline $31-40$ years & 10 & 3,8 \\
\hline $41-50$ years & 53 & 20,2 \\
\hline $51-60$ years & 112 & 42,6 \\
\hline $61-70$ years & 66 & 25,1 \\
\hline $71-80$ years & 19 & 7,2 \\
\hline$>80$ years & 2 & 0,8 \\
\hline Gender & $\mathrm{n}=263$ & \\
\hline Male & 216 & 82,13 \\
\hline Female & 47 & 17,87 \\
\hline Hypertension & $\mathrm{n}=191$ & \\
\hline Hypertension & 97 & 50,79 \\
\hline No Hypertension & 94 & 49,21 \\
\hline Diabetes mellitus & $\mathrm{n}=192$ & \\
\hline $\mathrm{DM}$ & 76 & 39,58 \\
\hline No DM & 116 & 60,42 \\
\hline Dyslipidemia & $\mathrm{n}=165$ & \\
\hline Dyslipidemia & 56 & 33,94 \\
\hline No Dyslipidemia & 109 & 66,06 \\
\hline Risk factors & $\mathrm{n}=151$ & \\
\hline $\mathrm{DM}+\mathrm{HT}$ & 48 & 38,7 \\
\hline HT+Dislipid & 26 & 9,3 \\
\hline DM+Dislipid & 47 & 37,3 \\
\hline HT+DM+Dislipid & 30 & 14,7 \\
\hline Systolic pressure & $\mathrm{n}=263$ & \\
\hline Normal & 93 & 39,6 \\
\hline Pre-Hypertension & 59 & 21,4 \\
\hline HT Stage 1 & 61 & 22,5 \\
\hline HT Stage 2 & 50 & 16,5 \\
\hline Diastolic pressure & $\mathrm{n}=263$ & \\
\hline Normal & 89 & 37,4 \\
\hline Pre-Hypertension & 102 & 45,1 \\
\hline HT Stage 1 & 50 & 16,5 \\
\hline HT Stage 2 & 22 & 1.1 \\
\hline
\end{tabular}

\section{Discussion}

Our data shows the ratio of male and female reached 4.5 $: 1$. The similar result was obtained in the research done by Irina F Prof. Kandou General Hospital, Manado in 2011 with 54 males with percentage of $67.5 \%$ and total of female were 26 with percentage of $32.5 \%{ }^{3}$ Gender was a factor that can affect heart function and caused heart attack. Male had more tendency with CHD risk factors such as alcohol, smoking, obesity and modern lifestyle that caused heart 
damage. Women suffered CHD in older age, over 60 years old, about 5-10 years slower than men. It was considered because of estrogen hormone gave protection to heart and blood vessels through increasing levels of High-Density Lipoprotein (HDL) or good cholesterol. ${ }^{3}$

Age is indeed one of the non-modified factors inherent in humans. It would also lead to a decrease in the functioning of organs including the weakening of the heart muscle contraction and heart rate. ${ }^{4}$ This could also lead to a decrease in the elasticity of blood vessels when draining blood, which would cause easy buildup of blood vessel plaque. If this occurrs continuously, it would resulting in atherosclerosis and narrowing the blood vessel lumen. Thus, blood to the heart will be hampered and CHD occurs. ${ }^{5}$ At the time, the condition of someone in the older age group will experience increased susceptibility to cardiovascular disease, including CHD. ${ }^{6}$ Degenerative processes appear in blood vessels so that atherosclerosis occurred and resulted in CHD that had an impact on myocardial infarction which increases up to 5 times. $^{7}$

Hypertension comorbid was one of the causes of CHD. Research conducted in the inpatient department of cardiology at Dr. Kariadi General Hospital, Semarang in the period of April - June 2011 the results of hypertension sufferers were more than 89 people with a percentage $69.50 .^{8}$ High blood pressure and sedentary would cause direct trauma to the walls of the coronary arteries. Therefore, it facilitated coronary atherosclerosis (coronary factors). This caused angina pectoris, coronary insufficiency and myocardial infarction which were symptoms of CHD more frequently found in hypertension patients compared to normal people. ${ }^{9}$ High blood pressure in the arteries continuously together with the presence of plaque accumulation of fat or blood flow so that the lumen of the blood vessels would become narrower. ${ }^{8}$

Based on this study, 39.6\% subjects suffered CHD with DM comorbid. From these results, it was also in line with several studies those carried out in Makassar's conducted that showed that $95.5 \%$ of the samples did not suffer DM. High number of differences from the results of this study because in the research conducted at Makassar, it used primary data on residents in the Makassar area in 2017. ${ }^{10}$ The research conducted by Supriyono 2008 resulted in 25 people suffering from DM who were also affected by CHD. ${ }^{3}$ Coronary and peripheral atherosclerosis were the main causes of morbidity and mortality in diabetics. In order to reduce cardiovascular risk in diabetes, it should carefully control blood glucose, correct obesity by diet and exercise, stop smoking, ${ }^{11}$ correction of abnormal plasma lipids, and control of blood pressure was important. ${ }^{12}$

According to this study, 56 patients (33.9\%) suffered from hypercholestrolemia with high LDL, on the other hand, 109 patients $(41.4 \%)$ had normal LDL. This was in line with research done in Internal Medicine og Dr. Kandou General Hospital, Manado of 9 people suffered from dyslipidemia with a percentage of $9.57 \%$. Increased or decreased levels of lipids in the blood greatly affected the process of atherosclerosis, one of the initial causes of CHD. In this process, increased levels of LDL cholesterol, increased levels of total cholesterol, increased triglyceride levels, and decreased HDL levels. This process could not be discussed individually but it was interrelated. Therefore, it was referred to as the "Lipid Triad". Atherosclerosis was a form of ateriosclerosis that mainly affected the intima layer and generally occurred in large and medium muscular arteries and it was an underlying disorder of ischemic heart disease. $^{13}$

$\mathrm{DM}$ is very influential in early atherosclerosis which can lead to CHD. In addition, the role of insulin is very influential in lipid metabolism.10 Uncontrolled DM will increase cholesterol and triglycerides. ${ }^{9}$

Study result done in 2017 Allauddin Makassar was obtained as a result of normal systolic blood pressure of less than $120 \mathrm{mmh}$ of 29 people with a percentage of $32.6 \%$ and it was the highest number. It was the result with the highest number compared to other hypertension stagging values based on diastolic pressure. ${ }^{10}$ It was also studied the stage of hypertension based on JNC VII obtained results that more risk factors associated with CHD were affected by hypertension 41 of 78 respondents $(60 \%) .{ }^{14}$ Different results were also shown in Kautzar Rizky's study of 611 respondents $60(9.8 \%)$ who were affected by hypertension. The differences in result from this study was due to differences in sampling and the time of research. Many aspects still out of discussion from this study, like lifestyle history from patients. This aspect is important to know if CHD condition may come from bad lifestyle, regarding the domination of lifestyle cause of CP from this study. Data about CHD patients in Indonesia is still minimal, thus many references coming from other country may have different sociodemographic background.

\section{Conclusion}

The most age range was 51-60 years, dominated by male patients. Risk factors of patients with coroner heart were hypertension, DM and dyslipidemia. The highest result shows comorbid hypertension and also accompanied by DM suffered CHD the most. Based on the criteria of JNC VII it is concluded that the blood pressure values in most patients were normal systolic pressure less than $120 \mathrm{mmHg}$ and pre-hypertension diastolic pressure $80-89 \mathrm{mmHg}$.

\section{Acknowledgement}

The researcher says thank you to all those involved in this writing. They cannot be mentioned one by one and thank you to the medical record staff of Dr. Soetomo General Hospital who helped in collecting data for this study.

Funding: No funding sources.

\section{Conflict of Interest}

The author stated there is no conflict of interest

\section{References}

1. DATIN I. Situasi Kesehatan Jantung. In: Indonesia PDdIKKR, (ed.). Edisi Hari Jantung Sedunia ed. Jakarta: Kementerian Kesehatan Republik Indonesia, 2014, p. 1-8.

2. Organization WH. Cardiovascular Diseases. Geneva: World Health Organization, 2016, p. 8.

3. Supriyono M. Faktor-Faktor Risiko yang Berpengaruh terhadap Kejadian Penyakit Jantung Koroner pada Kelompok Usia $<45$ Tahun (Studi Kasus di RSUP dr. Kariadi dan RS Telogorejo Semarang). Program Pascasarjana Universitas Diponegoro, 2008.

4. Soenarta AA, Erwinanto M and ASS B. R., Lukito, AA, Hersunarti, N.,... Pratikto, RS (2015). Pedoman Tatalaksana Hipertensi pada Penyakit Kardiovaskular. Pedoman Tatalaksana Hipertensi pada Penyakit Kardiovaskuler. 2015; 1: 1-2. 
5. Ghani L, Susilawati MD and Novriani H. Faktor Risiko Dominan Penyakit Jantung Koroner di Indonesia. Buletin Penelitian Kesehatan. 2016; 44: 153-64.

6. Iskandar I, Hadi A and Alfridsyah A. Faktor Risiko Terjadinya Penyakit Jantung Koroner pada Pasien Rumah Sakit Umum Meuraxa Banda Aceh. AcTion: Aceh Nutrition Journal. 2017; 2: 32-42.

7. Lilly LS and Braunwald E. Braunwald's Heart Disease: A Textbook of Cardiovascular Medicine. Elsevier Saunders, 2012.

8. Zahrawardani D, Herlambang KS and Anggraheny HD. Analisis Faktor Risiko Kejadian Penyakit Jantung Koroner di RSUP Dr Kariadi Semarang. Jurnal Kedokteran Muhammadiyah. 2012; 1.

9. Djohan BA. Penyakit Jantung Koroner dan Hipertensi. Medan: Universitas Sumatera Utara, 2004, p. 1-7.

10. Sari SRJ. Faktor Risiko Penyakit Jantung Koroner pada Pegawai Negeri Sipil UIN Alauddin Makassar Tahun 2017. Universitas Islam Negeri Alauddin Makassar, 2017.
11. Pratiwi DF. Evaluasi Penggunaan Obat pada Pasien Penyakit Jantung Koroner Rawat Inap di RSUD Dr. Moewardi Surakarta Periode 2009. Universitas Muhammadiyah Surakarta, 2011.

12. Marrugat J, Sala J and Aboal J. Epidemiology of Cardiovascular Disease in Women. Revista Española de Cardiología (English Edition). 2006; 59: 264-74.

13. Volkmann ER, Grossman JM, Sahakian LJ, et al. Low Physical Activity is Associated with Proinflammatory High-Density Lipoprotein and Increased Subclinical Atherosclerosis in Women with Systemic Lupus Erythematosus. Arthritis Care \& Research. 2010; 62: 258-65.

14. Syukri AEDP. Profil Penyakit Jantung Koroner di Irina F Jantung RSUP Prof. Dr. RD Kandou Manado. e-CliniC. 2013; 1. 